\title{
DEVELOPMENT OF THE PASSING CONTROLLING EXERCISE MODEL IN FUTSAL FOR JUNIOR HIGH SCHOOL STUDENTS
}

\author{
Setiya Yunus Saputra ${ }^{1}$, Widiastuti ${ }^{2}$ \\ ${ }^{1,2}$ Universitas Negeri Jakarta, Indonesia \\ ${ }^{1}$ setiyayunus@ymail.com*
}

\begin{abstract}
The purpose of this research was to develop a design of basic skill passing-controliing exercise model in futsal and to got empirical data about the effectiveness and efficiency of development of passing-controlling exercise model in futsal for junior high school students. The methods used in this research was research and development methodology from Borg and Gall, which it consist of ten steps. The subject of this research was the male students who participant in futsal extracurricular from junior high school in Malang City. The final result of this research and development were written on 28 handbook about passing-controlling exercise model in futsal for junior high school students that has been evaluated by experts, trial and revision, and the effectiveness has been tested. The implementation effectiveness of development of passingcontrolling exercise model for futsal extracurricular participants was used "t-test" technique. Before the data was analyzed, the normality was tested by Lilliefors test with $\alpha=0.05$ for pretest and posttest passing controlling futsal skills. The result of basic skill passing-controliing exercise model in futsal between pretest and posttest has to score $=4.536$ more than tt score= 1.711 , so the null hypothesis was rejected, and the mean of pretest score $\left(x_{1}\right)=11.66$ smaller than the mean of posttest score $\left(x_{2}\right)=13.53$. Based on this result, it would be declared that the passing-controlling exercise model in futsal for junior high school students was effective to improve their passing-controlling skill in futsal.
\end{abstract}

Keywords: exercise model; passing controlling futsal.

In futsal, besides mastering any other techniques, every player must master basic techniques like passing and controlling. The reason is that $80 \%$ of basic technique used in playing futsal is passing-controlling technique.

Passing and controlling play an important role in futsal because of 2 (two) reasons. The first reason is the chance to control the ball, to open the opponent's defensive area. The second reason is to keep the team's ball possession. If players do not have good controlling technique, those situations will not happen. Accurate and precise passing and controlling will give their team more chance to score. Vic Herman and Rainer Engler said "Futsal has incredibly fast passing, and is the epitome of a team sport that still allows room for individual demonstrations of skill, tricks and feints that are relished by players and spectators a like".

Based on the observation of need analysis conducted, it was found out that students of one of junior high schools in Malang joining Futsal extracurricular were not motivated to train their basic techniques in futsal, especially the passingcontrolling techniques. It was also found out that their passing-controlling techniques were not really good in terms of precision and quality. Therefore, based on the observation conducted, coaches and students joining futsal extracurricular need the new passing-controlling exercise model to motivate students and to improve students' quality of technique in futsal. 
Based on the background above, the researcher wants to develop passing and controlling exercise models. The researcher will develop passing controlling exercise models for junior high school students.

\section{Theoretical Review}

\section{Model Development Concept}

Model development is the research result of product development oriented. Research and development can produce a product and the product's effectiveness can be tested. Winarno explained that "A development research is a research aiming to develop certain product in accordance with the society's current need. Therefore, the research and development conducted must get through some processes and steps so the new product or the improved product can be counted for the result and the benefit. The process of development research is circular. It starts with analysis, design, evaluation and revision until the desired result is obtained.

\section{Model Concept Developed}

In this research, the concept developed is the concept of exercise model development. Exercise is an effort to improve function quality of body organs of the doer. Kent in Budiwanto said that "Exercise is a physical training program planned to help an athlete master skills, improve his body fitness, and prepare him for some matches".

Bompa in Budiwan said that exercise is a systemic sport activity in a long period, which is improved gradually, and individually to create a person functioning physiologically and psychologically to fulfill his task.

\section{Theoretical Framework Motor Learning}

The American Heritage Dictionary defines study as: "to gain knowledge, comprehension, or mastery through experience or study.” It means that studying is adding knowledge, understanding or mastery through experience or learning.

William stated that "Motor learning is the study of the processes involved in acquiring motor skills and of the variables that promote or inhibit such acquisition". Schmidt had a better explanation for this saying that "motor learning is the changes associated with practice or experiences in internal process that determine the person's capability for producing a motor skill".

In the process of learning, someone surely cannot directly master a skill really well and correctly. They must get through series of learning. Fiits and Postner in William H. Edward said that “... Fitts and Posner model identifies three stages in the acquisition of motor skills: cognitive, associative, and autonomous”.

\section{Motor Skill}

Motor skill is someone's ability to do a motor task maximally in accordance with his ability. The basic nature of skill is to push someone to consider more when he plans to learn from experience. William said that "A motor skill is one in which the primary determinant of success is the quality of movement".

In acquiring motor skill, there are three components that affect its performance. To show a good motoric performance, those three components must be counted 
really well. Those components are someone who is doing the skill (person), the duty (task) and the place where the skill is performed (environment).

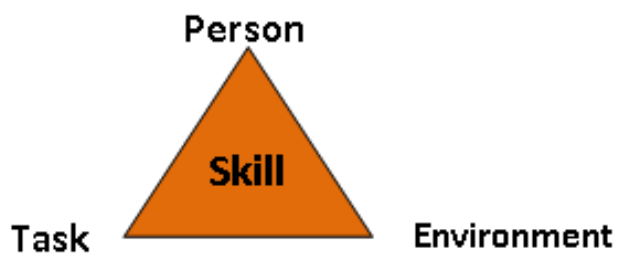

Picture 1. The Study of Motor Skill Encompasses Three Component Influencing Performances. (Source: William H. Edward. Motor Learning and Control. (Wadsworth: USA, 2010), h.42.

\section{a. Person}

Every person can interact in different ways depends on experience, various kinds of instruction and feedback, and the exercise. By studying the difference of individual and exercise, information regarding the nature of the exercise and the process affecting learning can be obtained.

William said that:

"The attributes of individual persons play a significant role in shaping the performance of motor skills. Each person brings a unique composition of innate abilities, physical characteristics, psychological traits, previous skill-learning experiences, age, and motivation to the performance of motor skills".

It means that skills learned by people will be different depends on someone's condition such as physical characteristic, psychological feature, experience, age, and motivation.

b. Task

Motoric skill task varies. It depends on the objective and motoric demand in certain skills. William said that "Tasks also vary relative to the perceptual demands they place upon individuals.”

Many motoric skills need high perception demand. A baseball player has to determine the speed and ball line accurately when he hits the ball. A goal keeper has to block the ball coming from unexpected angles quickly. Other tasks need equipment manipulation to work successfully for example bowling, hammering nails, and kicking a ball. Those sports need body movement coordination in limitation set by external objects. Sport skills can also limit movement and affect task performance quality.

c. Environment

The skill can be performed in predicted or unexpected environment which is similar or dissimilar with training condition, recreation or competition. The skill can be performed by an individual or before others involving other players also spectator. The individual physical condition also affects the performance characteristic. Lightening condition, temperature, wind direction and gravity can be substantially influence the skill performance. Eventually, the fully understanding of motoric task is taken from the appreciation of the interaction of third components contributing of their skill performance.

Thus, an individual must consider also the environment where she/he will perform the motoric performance. It has in line with William opinion: 
The third component influencing skill performance is the environment in which a person executes the skill. Where will a motor task be performed? What is the environmental context of performance?

\section{The characteristic of Junior High School Students}

"Adolescence is a time of much physical, emotional, and intellectual growth in a person's life”. According to Sri Rumini \& Siti Sundari, adolescence is the transmission from childhood to maturity experiencing all aspects or functions of development becoming maturation. The range of teenage age usually is divided into three stages namely 12 - 15 years = the early stages of maturation, 15 - 18 years = the middle stages of maturation, and 18 - 21 years = the final stages of maturation.

The psychomotor skill at teenage comes along with the development of body, physical ability and the physiology change. Nowadays boys have developed faster psychomotor than girls' psychomotor. Boys' Psychomotor ability tends to increase in strength, agility and durability.

\section{Basic skill of Futsal}

Lhaksana explained that the necessary ability to excel Futsal basic techniques namely (1) passing, (2) controlling, (3) chipping, (4) dribbling, (5) shooting.

\section{Passing}

Passing is a basic technique of kick which is used to receive or pass the ball in short distance and every player must excel it. According to Scheuneman, having accurate passing for a futsal player is paramount because passing is often performed at any game. Passing can be executed by any part of foot however the ball's angle must contact the surface or swipe the ground. Thus the foot or shoe touches the ball at the same time of passing must be exact at the middle of the ball.

The passing technique will be explained further as follows:

a) Passing technique with the inside of the foot

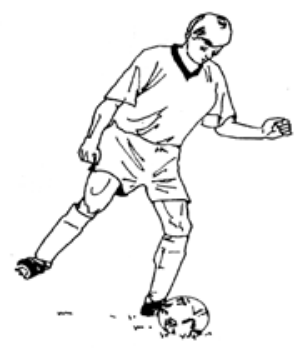

Preparation Step

Picture 2. The step of preparation passing with the inside of the foot. (Source: Joseph A. Luxbacher. Football: steps to success, translated by Agusta W (Jakarta: Rajagrafindo Persada, 2004) p.12.

The activities that must be performed on: preparation step; (1) standing facing the target; (2) positioned foot is placed next the ball; (3) directing the kicking leg toward the target, shoulder and hip width along the target; (4) raising slightly the cocked knee; (5) swinging the kicking foot backward; (6) placing the foot at the side 
position, (7) stretching the hand to keep the balance; (7) head does not move and focuses on the ball.

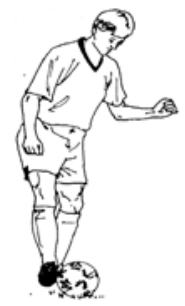

Implementation Step

Picture 3. The step of Implementation passing with inner foot. (Source: Joseph A. Luxbacher. Football: steps to success, translated by Agusta W (Jakarta: Rajagrafindo Persada, 2004) p.12.

The movements that must be performed on Implementation step: (1) positioning the body up to the ball, (2) swinging the kicking foot forward; (3) staying the foot to be straight, and (4) kicking the center of the ball with the inside of the foot.

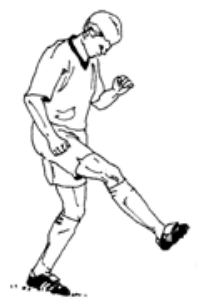

Further Movement Step

Picture 4. Further movement step passing with inner side of foot (Source: Joseph A.

Luxbacher. Football: steps to success, translated by Agusta W (Jakarta:

Rajagrafindo Persada, 2004) p.12.

The movements that must be performed on further technique: (1) shifting the body weight forward, (2) Following through the direction of the ball, and (3) the movement ends smoothly

(b) Passing technique with outside of the foot

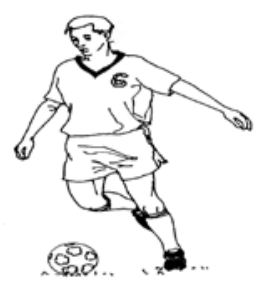

Preparation Step

Picture 5. Preparation Step Passing with the outside of the foot (Source: Joseph A. Luxbacher. Football: steps to success, translated by Agusta W (Jakarta: Rajagrafindo

Persada, 2004) p.14 
The movement that must be performed on preparation step namely: (a) standfacing the target (b) placing the cocked foot at the side back of the ball, (c) directing the foot at the target; (d) shoulder and hip width along the target; (e) raising slightly the cocked knee; (f) swinging the kicking foot backward and directing straightly the foot underneath; (g) pivoting to inside, stretching the hand to keep the balance; (h) head does not move and heads on the ball.

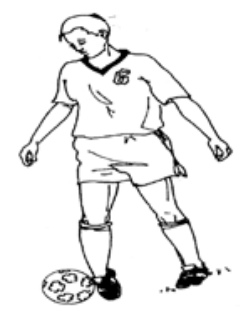

Implementation Step

Picture 6. Implementation Step Passing with the outside of the foot (Source: Joseph A.

Luxbacher. Football: steps to success, translated by Agusta W (Jakarta:

Rajagrafindo Persada, 2004) p.14.

The movements that must be performed on Implementation step namely; (a) bowing the head and positioning the body up to the ball; (b) swinging the kicking foot forward; (c) keeping the foot straightly; (d) kicking the center of the ball with the outside of the foot.

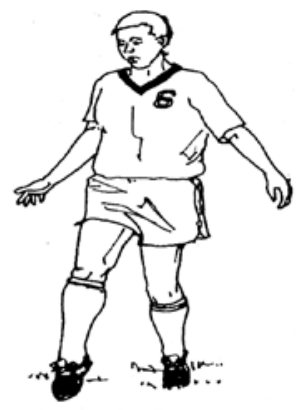

Step of Further Movement

Picture 7. Further movement step, passing with the outside of the foot (Source: Joseph A.

Luxbacher. Football: steps to success, translated by Agusta W (Jakarta:

Rajagrafindo Persada, 2004) p.14.

The movements that must be performed on Implementation step namely; (a) shifting the body weight forward; (b) following the movement to kick reversely; (c) then perfecting the last movement from the kicking foot.

\section{Controlling}

Controlling is the basic technique to control or stop the ball which moving directly to the opposite player. This basic technique is used together with passing technique and is performed to arrange the play pace, to distract the game speed, and to ease the passing. However in futsal $80 \%$ of controlling is using sole of foot. The 
range of controlling technique basically is performed by three steps, namely: (1) Step of Preparation (2) Step of Implementation and (3) Step of Further movement.

Meanwhile the styles of controlling technique will be explained as follows:

a) Controlling technique with sole of foot

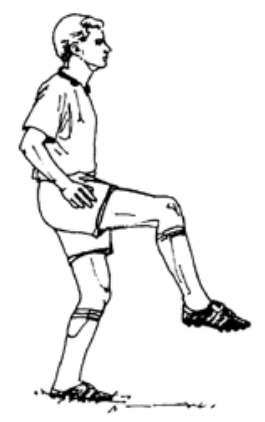

Step of Preparation

Picture 8. The Preparation Step of Controlling with sole. (Source: Joseph A. Luxbacher.

Football: steps to success, translated by Agusta W (Jakarta: Rajagrafindo Persada, 2004) p.22.

The movement that must be performed namely: (1) facing to receive when the ball comes toward the player, (2) raising the foot to receive approaching ball on estimation of the height level of the ball and keeping the foot steady. (3) Leaning the cocked knee (4) stretching the hand to keep balance, head is steady and (5) focusing on approaching ball.

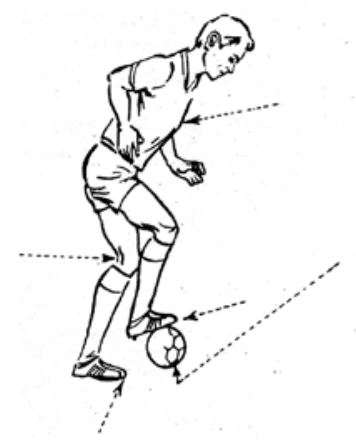

Step of Implementation

Picture 9. Step of Implementation Controlling with sole of foot. (Source: Joseph A.

Luxbacher. Football: steps to success, translated by Agusta W (Jakarta:

Rajagrafindo Persada, 2004) p.22.

The movements that must be performed on Step of Implementation such as: (1) swifting the body weight forward, (2) receiving the ball with the sole of foot, (3) pulling the foot slightly up for reducing rebound, and (4) guarding the ball from the opposite players. 


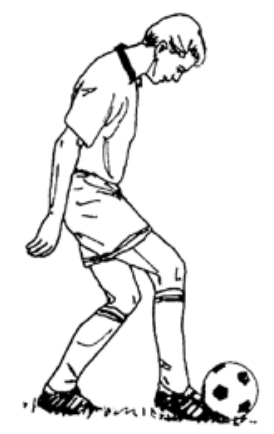

Step of Further Movement

Picture 10. Step of Further Movement. (Source: Joseph A. Luxbacher. Football: steps to success, translated by Agusta W (Jakarta: Rajagrafindo Persada, 2004) p.22.

The movements that must be performed on the Step of Further Movement: (1) pushing the ball to the free zone while observing the field situation.

The final purpose of this development research is to produce a book product of training model passing-controlling which can give benefit to the trainers in order to ease them in training material implementation.

\section{METHOD}

The development research of training model of passing-controlling in Futsal uses the model of research and development from Borg and Gail which consists of ten steps such as: (1) Performing the research and data collection (References, Subject Observation, the report preparation of main problem) (2) Performing the planning (skill definition, the aim of formulation, teaching arrangement determination, and test experiment of minor scale) (3) Developing the formation of early product (the preparation of teaching material, hand book compilation and evaluation complement) (4) Performing the beginning of field test (using 6-12 subjects) (5) Performing revision to main product (concur with the suggestions from the beginning of field test) (6) Performing the primary field test (with 30 - 100 subjects). (7) Performing product revision (based on suggestions and the result of primary test field). (8) Conducting field test with 40-200 subjects. (9) Revising the final product. (10) Making the report regarding products on journal, working with the publisher who able to distribute commercially.

The research uses the quantitative approach which aims to find out the answer of the problem through formulation of the problem that been developed on Chapter I that is training model of passing-controlling on students of Futsal extracurricular training.

The final result of the development research is the training model of passingcontrolling will outcome the product such as new design of training model or complete its previous one with specification product also examine the effectiveness of the training model that been designed so it can improve the accuracy and quality and can be used as a guideline in training activity of basic technique of Futsal passing-controlling. 


\section{RESULTS AND DISCUSSION}

Based on the test result of effectivity using ttest, from the result differences of basic training Futsal passing-controlling between pre-test with post-test, it was obtained the value of to $=4.536$ greater than value of $t t=1.711$ (on significance degree of 0.05 ) so the null hypothesis, in this case, was rejected. it could be concluded that there was a significant difference between the result of pre-test and post-test of basic skill Futsal passing-controlling.

Taken from research data, it was obtained that the value of the average pre-test $(\mathrm{X} 1)=11,66$ smaller than the value of the average post-test $(\mathrm{X} 2)=13,53$. Therefore it could be concluded that training model of Futsal passing controlling for junior high school students is effective to be used in order to improve the result of Futsal passingcontrolling skill.

\section{CONCLUSION}

Taken from the result of Field test and discussion, the result research can be concluded as follows:

1. Based on the evaluation result from expertises and test result which were conducted, it was obtained the final model or the final of training of Futsal passing-controlling consisted of:

(1) Passing controlling I (Static Passing ), (2) Passing controlling II (Balance Passing Control), (3) Passing controlling III (Triangle), (4) Passing controlling IV (Back and Forth), (5) Passing controlling V (All Directions), (6) Passing controlling VI (Square), (7) Passing controlling VII (Rectangular), (8) Passing controlling VIII (Left Right), (9) Passing controlling IX (Diagonal), (10) Passing Controlling X (Basic), (11) Passing controlling XI (Push Passing), (12) Passing controlling XII (Change Position), (13) Passing controlling XIII (Two-way), (14) Passing controlling XIV (Power Passing), (15) Passing controlling XV (Eye Of The Wind), (16) Passing controlling XVI (Zig Zag Passing), (17) Passing controlling XVII (Target), (18) Passing controlling XVIII (Concentration), (19) Passing controlling XIX (Wall pass), (20) Passing controlling XX (Passing Accuracy, (21) Passing controlling XXI (Shooting Accuracy), (22) Passing controlling XXII (Moving), (23) Passing controlling XXIII (Diamond), (24) Passing controlling XXIV (Change Position), (25) Passing controlling XXV ( Small Game), (26) Passing controlling XXVI (Game Target), (27) Passing controlling XXVII (Game Situation) and (28) Passing controlling XVIII (Game).

2. Based on the test result of model effectiveness, it indicated empirically that the product result of model training Futsal Passing-Controlling for Junior High School has good effectiveness. It is based on the test result of Futsal PassingControlling skill showing the the value of the average post-test greater than the value of the average pre-test. Therefore, it can be stated that the model training of Futsal Passing-Controlling for Junior High School is effective to be implemented in order to improve the training result of Futsal PassingControlling skill for Junior High School. 


\section{Implication}

Based on the conclusion of the test research entirely shows that the product of training result of Futsal Passing-Controlling skill for Junior High School is effective and worthy to be implemented on Futsal extracurricular training. So, the implication of this research finding is the training result of Futsal Passing-Controlling is supposed to be considered by the teacher or trainer as another alternative guideline or reference for training activity of Futsal Passing-Controlling skill for Junior High School because it is effective to be implemented in order to in order to improve the training result of Futsal Passing-Controlling skill.

\section{Suggestions}

\section{Benefit Suggestion}

This product development is the development skill of training model of Futsal Passing-Controlling for Junior High School. If the development skill of training model of Futsal Passing-Controlling is implemented in every Futsal extracurricular at school, so it is better for the school administration to provide applicable facilities which meet with the need for that activity. The facilities which need be required properly to support the activity such as financing, the facility/vehicle or infrastructure.

Notwithstanding, if the training model of Futsal Passing-Controlling for Junior High School which will be invested as the guideline book of Futsal extracurricular at school therefore the teacher or trainer of Futsal extracurricular for better result improve his/her professional skill in order to implement this model effectively and efficiently at Futsal extracurricular training.

\section{Suggestion of Dissemination}

The training model of Futsal Passing-Controlling for Junior High School which is realized as the guideline book can be proven empirically having good effectiveness to improve the skill of Futsal Passing-Controlling for Junior High School, it can be distributed to a widely target particularly to the teacher or trainer of Futsal extracurricular for Junior High School. However, before disseminating the researcher gives suggestion that the guideline book of the training model of Futsal Passing-Controlling for Junior High School needs to be published with greater number so the teacher or trainer of Futsal extracurricular for Junior High School can understand and able to excel the basic technic of improved Futsal PassingControlling.

\section{Suggestion for Further Development}

In order to develop further the product of training model of Futsal PassingControlling for Junior High School, the researcher has several suggestions namely: (a) the development product of training model of Futsal Passing-Controlling for Junior High School still needs further examination and experiment test intensively and continuously also is applied to the greater extend which having diverse characteristics (heterogeneity) as an effort to attain a response in order to conduct the product perfection; (b) the involving subjects on this research and experimental test need to be supported fully by many experts or Futsal experts also trainers of Futsal extracurricular as users and the students as subjects; (c) an examination needs to be conducted for further development at the level of variance and adjustment of 
level of age which expecting the variety of model that innovate and stimulate students/participant to be more enthusiastic in Futsal extracurricular training; (d) it is expected that there will be a researcher who can develop the model training of Futsal basic technique overall which not only the technique of Passing-Controlling.

\section{REFERENCES}

Budiwanto, Setyo. Metodologi Latihan Olahraga. Malang: UM Press, 2012.

Herman \& Rainer Engler, Vic. Futsal Technique Tactics Training. UK; Meyer \& Meyer Sport. 2011

http://www.dsdguidelines.org/htdocs/parents/adolescence.html (diakses 28 April 2015)

Joseph A, Luxbacher. Sepak Bola: Langkah-Langkah Menuju Sukses, terjemahan Agusta W. Jakarta: Rajagrafindo Persada, 2004.

Lhaksana, Justinus. Teknik dan Strategi Futsal Moder. Jakarta: Be Champion, 2011.

Scheunemann, Timo. Futsal for Winners. Malang: Dioma, 2009.

Sugiyono. Motode Penelitian Pendidikan, pendekatan kuantitatif, kualitatif dan $R \& D$. Bandung: Alfabeta, 2008.

Sudari, Sri Rumini \& Siti. Perkembangan Anak dan Remaja. Jakarta: Rineka Cipta. 2004.

Tudor, Bompa. Theory and Methodology of Training. Iowa: Kendal Publishing Company, 2009.

The American Heritage Dictionary: https://ahdictionary,com/ (diakses 22 November 2014).

Winarno, M. E. Metodologi Penelitian Dalam Pendidikan Jasmani. Malang: Media Cakrawala Utama Press. 2011. 